\title{
THE PENNSYLVANIA FIDUCIARIES ACT OF 1949.
}

Two years ago, Pennsylvania gathered together its rules relating to the administration of decedents' estates, minors' estates, trust estates, and the like, in a new Fiduciaries Act. ${ }^{1}$ In many respects the Act is declaratory of previously existing law, principally the 1917 Fiduciaries Act ${ }^{2}$ and its amendments, but there are significant changes. Many of the problems left unsettled, or newly raised, spring from what the Act has left unsaid. It is uncertain if the Act is substitutional or additional, whether it states the whole of the law relating to fiduciaries, or whether it leaves unaltered those areas and rules which it does not specifically deal with, or deals with only in part. The Act's repealer provision ${ }^{3}$ excepts enough previous legislation to raise a doubt as to its nature and scope. Because of this doubt, and because of the broad equitable powers of the Orphans' Courts, many of the provisions of the Act are open to broad interpretation. If the courts are loath to part with some of the traditional rules applicable to decedents' estates, such as the judicial power to restrain sales made by a personal representative, ${ }^{4}$ and the order of abatement of a decedent's property, ${ }^{5}$ the changes made by the Act may not be as effective as they purport to be.

It is not the purpose of this symposium, however, to dwell at length on the nature and scope of the Act, or deal with its problems on a conceptual basis. ${ }^{6}$ Where such an analysis is believed helpful it will be made briefly, but the authors of the comments below are more concerned with practical problems raised by some of the provisions of the Act, both by the language itself, and by the effect of that language in the light of the preexisting peculiarities of Pennsylvania's law of decedents' estates. Rather than attempting a definitive study of the Act at this early date, certain specific areas have been selected with an eye to their practical importance and to the magnitude of the changes made. ${ }^{7}$ It is sought first to outline the effect of the Act's provisions in these areas and, secondly, to deal with the problems that are raised with respect to them.

1. PA. Stat. AnN., tit. 20, $\$ 320.101$ et seq. (Purdon, 1950). Hereinafter, the Act will be referred to by section number only, e.g., $\S 101, \S 545$.

2. Formerly, PA. Srat. ANN., tit. 20, §321 et seq. (Purdon, 1941). Hereinafter, this act will be referred to as Act of 1917 , followed by the Purdon section number.

3. $\S 1401$.

4. See text infra beginning at note 121 .

5. See text infra beginning at note 142 .

6. It is a matter of doubt, for instance, whether the Act abolishes, or merly supplants, the concept of the lien of creditors on decedents' real property. See notes 9 and 86 infra. Regardless of the answer, creditors have certain remedies, by whatever name they may be called. The Lien concept is only of importance where no such remedy is specifically given. See notes 86 and 119 infra and text.

7. The Law Review is greatly indebted to Philip Bregy, Esquire one of the Commissioners who framed the Act, professor at the University of Pennsylvania Law School, and member of the Philadelphia bar, for his invaluable assistance in aiding us in the selection of problems for discussion and in their presentation. 


\section{Historical Note}

In dealing with the administration of decedents' estates, the 1949 Act represents a desire to simplify that administration, principally by an assimilation of real and personal property. In so doing, the Act has made a fundamental change in the Pennsylvania law of decedents' estates.

Pennsylvania imported this branch of its law from England, where the law governing the devolution of real property grew up under different rules and in a different system of courts than the law governing the devolution of personalty. The passage of realty was handled by the common law courts, and land passed directly from the decedent to his heir or devisee without a process of administration. The heir established his title in an ordinary action in the common law courts; the devisee had to establish the proper execution of the will, there being no probate proceeding whereby the validity of the will could be conclusively established at common law. Real property acquired by the testator after the execution of the will could not pass by that will, even under a residuary devise, because a devise of land was thought of as operating at the date of execution, subject to postponement of operation until the testator's death. Land could not be sold for the payment of debts, other than specialty debts, unless the will so specified.

Personal property, on the other hand, was under the jurisdiction of the ecclesiastical courts. It passed to the personal representative of the decedent, who distributed it to the legatees or those entitled to take by intestacy, after discharging the debts of the decedent. The probating of the will was conclusive as to a bequest of personalty, and a will of personal property was construed to take effect from the date of the testator's death, allowing after-acquired property to pass under it. ${ }^{8}$

In several respects Pennsylvania had broken away from the English system by assimilating the rules of realty to those of personalty prior to the 1949 Act. As early as the Act of May 31, 1693, all lands were made liable for the payment of debts. ${ }^{9}$ The Act of April 10, 1833, provided that after-acquired realty should pass by a general devise. ${ }^{10}$ This was extended by the Act of June 4,1879, which provided that wills should be construed to speak and take effect as if executed immediately before the testator's death, as to both realty and personalty. ${ }^{11}$ By the end of the nineteenth century probate of a will was conclusive as to both realty and per-

8. See Leach, Cases on Wilts 1-5, 141-142 (2d ed. 1949); MEchem aNd Atkinson, Cases on Wirls 457-461 (3d ed. 1947).

9. See Ladner, Conveyancing in Pennsylvania 395 (2d ed. 1941). The provisions of the earlier statutes that a decedent's realty was subject to sale for the payment of debts not satisfied out of personalty were construed to place a lien on the land. Even in the hands of a bona fide purchaser from an heir or devisee, the land was subject to the claims of an unpaid creditor. Morris, Lessee v. Smith, 1 Yeates 238 ( $\mathrm{Pa} .1793$ ). For the possible application of the lien theory under the 1949 Act, see note 86 infra and text.

10. P.L. $249, \S 10$.

11. P.L. $88, \S 1$. 
sonalty unless attacked by an appeal from probate. ${ }^{12}$ As to intestate succession, the Intestate Act of $1917^{13}$ removed the last vestiges of the old distinction in that area by providing for inheritance of both real and personal property in accordance with the scheme for the distribution of personal property as found in the English statute of Distribution of 1670.14

The assimilation was only partial, however. Although land was an asset for the payment of debts in Pennsylvania as early as the seventeenth century, before the Act of 1949 it was not an asset under control of the administrator except by order of the Orphans' Court; nor was it handled by the executor unless control of it was given either by will or court order. ${ }^{15}$ Under the new Act all real estate, except that occupied by an heir or devisee, is given to the possession of the personal representative without the need for court authority. In the excepted cases the court may direct him to take possession if necessary. ${ }^{16}$ The personal representative may lease any property which he is entitled to possess. The personal representative is also given the power to sell all real estate except that specifically devised without order of court. ${ }^{17}$ As under former practice he may sell property specifically devised under court order. ${ }^{18}$ Because of the broad powers given the personal representative provision is made for restraint of improvident sale. ${ }^{19}$ The powers of the personal representative over realty continue until the decree of distribution, which follows the filing and auditing of an account, much as has heretofore been done in the case of personal property. ${ }^{20}$

Despite the broad powers over real estate given the personal representative, this Act does not go as far toward complete assimilation as the English Administration of Estates Act, ${ }^{21}$ which provides that realty as well as personalty shall pass to the personal representative. Under the Fiduciaries Act of 1949 legal title to personalty passes to the personal representative ${ }^{22}$ and legal title to realty passes to the heir or devisee, subject to the powers of the representative. ${ }^{23}$ Two reasons have been advanced to explain why title to realty was not vested in the personal representative. First, if title to realty were given initially to the personal representative, there would be questions as to the marketability of title in the case of a small estate which did not pass through administration. Even in

12. Pa. Stat. AnN., tit 20, $\$ 1886$ (Purdon, 1930).

13. PA. Stat. AnN., tit. 20, $\$ 1.3,1.4$ (Purdon, 1950). For comment, see Bregy, Pennsylvania Intestate, Wills and Estate ACT of 1947, 155 (1949).

14. 22 and 23 Charles II, c. 10.

15. Act of $1917, \S 551$.

16. $\S 501$.

17. $\$ 542$.

18. $\S 541$.

19. $\$ 543$.

20. $\$ \S 731-736$.

21. 15 GEo. V, c. 23 (1925).

22. $\$ 103$.

23. $\$ 104$. 
the present Act, however, the small estate has been given special consideration. $^{24}$ This could be done under a system of total assimilation. A less persuasive reason for retaining the distinction is that title searchers are used to having title pass directly to the heir or devisee. While there may be no sound reason for retaining this distinction, still there appears to be no real need to abolish it at the present time. Under the new Act the powers of the personal representative seem adequate for efficient administration.

\section{The Application of the Act to Revocable Trusts}

Generally speaking, the Act is designed to take effect on January 1, 1950. The draftsmen of the Act determined, however, that certain sections of Article IX, Trust Estates, should apply only to testamentary or irrevocable trusts created on or after the effective date of the Act, but should apply to revocable trusts whenever created. ${ }^{25}$ Briefly, the sections provide for majority control by the trustees, ${ }^{26}$ power of the trustees to sell the res of the trust, ${ }^{27}$ power of the court to grant an option to sell, ${ }^{28}$ and the right of the trustees to pay a minor's income directly to the minor. ${ }^{29}$ The Commissioners, in their comments, indicate that the rather peculiar distinction was prompted by a fear of running afoul of the constitutional provision protecting vested rights. ${ }^{30}$ The excepted sections are those which most radically change the rules of administration. That the fears of the Committee were well-founded has been repeatedly pointed

24. $\$ 615$. In England, there has long been a total assimilation of realty and personalty in the administration of decedents' estates. The Iand Transfer Act of 1897 allowed probate of a will which disposed only of realty and provided that real as well as personal property should vest in the personal representative and pass to heirs and devisees only by assent or conveyance of the personal representative. These provisions were continued in the Administration of Estates Act of 1925. The latter also assimilated the rules of intestate succession of real and personal property. Mechen \& Atkinson, Cases on Wills and Administration 460 (1947).

25. \$105: "Effective Date-This act shall take effect on the first day of January, one thousand nine hundred and fifty, subject to the following exceptions:... (2) Trust Estates. Sections 949 entitled Disagreement Among Trustees, 961 entitled Power to Sell, 963 entitled Order of Court, insofar as it authorizes the court to approve the grant of an option, and 984 entitled Disposition of Minor's Income, shall apply to testamentary trusts and irrevocable trusts only if becoming effective on or after that day but shall apply to revocable trusts whenever created. As to testamentary trusts and irrevocable trusts effective before that day, the existing laws on the topics included within such sections or designated portions thereof shall remain in effect."

Subsection 3 of $\$ 105$ makes similar provisions relating to Subsection (a) of $\$ 1045$ entitled "Guardian Named in Conveyance." The instant discussion is limited to subsection (2) of $\S 105$ but it is believed that the principles here involved apply equally to Subsection (3).

26. $\S 949$.

27. $\$ 961$.

28. $\$ 963$.

29. $\$ 984$.

30. Commissioner's Comment to $\S 105(2)$ - "The exceptions listed are instances where it is believed a retroactive application would disturb vested property rights." 
up in recent Pennsylvania decisions. ${ }^{31}$ The Supreme Court has indicated a very unfavorable attitude toward the retroactive application of statutes which may disturb "vested rights." 32 The extreme protection indicated in these decisions would seem to cast some doubts upon the constitutionality of the present Act even when the retroactivity of the indicated sections is limited to revocable trusts. An examination of the cases in the field is here attempted in an effort to indicate the arguments both for and against the application to revocable trusts and to give some reasonable basis upon which to predict the result if such a question should arise.

Pennsylvania has a long and somewhat oscillating case history on the question of what type of retroactive legislation may or may not be imposed by the legislature. ${ }^{33}$ It has been said repeatedly, however, and adopted as the position of the present court, ${ }^{34}$ that a statute which impairs a vested right is unconstitutional as applied retrospectively. ${ }^{35}$ An analysis of the interests created by a revocable trust is the first step in determining constitutionality.

The quality of the interest of the beneficiaries of revocable trusts has most frequently arisen in cases involving widow's rights. Normally the widow is seeking to have the trust res declared a part of her husband's estate for the purpose of her taking against the will. The court has repeatedly decided that such a trust, unless the trustee is constituted a mere agent of the settlor, is an inter vivos trust and the interest of the remaindermen is a vested interest. ${ }^{36}$ In this regard the court has frequently found it necessary to define the nature of the power of revocation. It has consistently been held that the power, unexercised, is to be treated as though it never existed. ${ }^{37}$ Professor Scott has stated that "the reservation of a power of revocation does not prevent the creation of a trust in the lifetime of the settlor, and the beneficiary at once acquires a future interest, although it is an interest subject to be divested by the exercise of the power. The death of the settlor is not a condition precedent to the vesting of the interest in the beneficiary." 38

31. McKean Estate, 366 Pa. 192, 77 A.2d 447 (1951); Crawford Estate, 362 Pa. 458, 67 A.2d 124 (1949); Borsch Estate, 362 Pa. 581, 67 A.2d 119 (1949).

32. 99 U. of PA. L. REv. 864 (1951).

33. Compare Palairet's Appeal, $67 \mathrm{~Pa} .479$ (1871), and Ervine's Appeal, $16 \mathrm{~Pa}$. 256 (1851), with Canovaro v. Order of St. Augustine, $326 \mathrm{~Pa} .76,191$ Atl. 140 (1937); Grim v. Weissenberg School District, $57 \mathrm{~Pa} .433$ (1868).

34. McKean Estate, 366 Pa. 192, 77 A.2d 447 (1951).

35. E.g., Willcox v. Penn Mutual, 357 Pa. 581, 55 A.2d 521 (1947) ; Palairet's Appeal, $67 \mathrm{~Pa} .479$ (1871); Ervine's Appeal, $16 \mathrm{~Pa}$. 256 (1851).

36. E.g., Lines v. Lines, $142 \mathrm{~Pa} .149,21$ Atl. 809 (1891); Dickerson's Appeal, $115 \mathrm{~Pa}$. 198, 8 Atl. 64 (1886). These cases and many others frequently cited are expressly concerned with determining whether the trust is inter vivos or testamentary, but the Pennsylvania court views them as also holding that the beneficiary has a vested interest. See McKean Estate, $366 \mathrm{~Pa}$. 192, 77 A.2d 447 (1951).

37. See Dolan's Estate, 279 Pa. 582, 589, 124 Atl. 176, 178 (1924); Lines v. Lines, supra note 36 at 167,21 Atl. at 810, 811; Dickerson's Appeal, supra note 36 at 210,8 Atl. at 69 . See 99 U. of PA. L. Rev. 879 (1951).

38. 1 Scott, Trusts 337,338 (1939). 
The issue has also arisen in a line of inheritance tax cases in which the court has again viewed the beneficiaries' interest as vested, but, by reason of the tax statute, has held the fund taxable at the death of the settlor. $^{39}$ These cases in no wise weaken the firm conceptual position that the mere reservation of the power to revoke does not alter the vested character of the remainderman's interest. Nor do they necessarily indicate that the Pennsylvania court will abandon the conceptual position in other cases. The tax is imposed upon the theory that the settlor has not parted with full control of the res. ${ }^{40}$ To find an interest taxable, therefore, is not to find that it has not vested in the sense that it cannot be retroactively impaired. ${ }^{41}$

With regard to the settlor's interest, as recently as 1949 the Pennsylvania court has held that the settlor of a spendthrift trust has a vested property right to have the trust carried out as directed by him. Hence a statute allowing the life tenant to release his interest to the remainderman was unconstitutional as applied retroactively. ${ }^{42}$ Irrespective of whether or not the soundness of this decision is open to question, ${ }^{43}$ it stands as a possible analogy to the situation under discussion.

Even though the interests of beneficiary and settlor are vested, the question remains whether they are disturbed sufficiently by section 105 to render the Act unconstitutional in this respect. With regard to the beneficiaries' interest, the retroactive application of the Principal and Income Act was recently held unconstitutional by reason of its affecting the vested rights of the beneficiary. ${ }^{44}$ In that case, however, the effect of the legislation was to affect substantively the return to be realized. The classic formulation of the policy of the due process clause, as applied to vested rights, was being violated. ${ }^{45}$ Property which, prior to the act, would have gone to $A$ was, under the new provisions, being given to $B$. On the other hand. the Revised Price Act of 1917, which authorized the court to confirm the sale, mortgaging of, or partitioning of land acquired by descent or will, was held constitutional, even though some of the persons owning

39. Todd's Trust, $358 \mathrm{~Pa}$. 530, 58 A.2d 135 (1948); Glosser's Trust, $355 \mathrm{~Pa}$. 210, 49 A.2d 401 (1946); Lines Estate, 142 Pa. 149, 21 Atl. 809 (1893); but cf. Dolan's Estate, supra note 37.

40. See cases cited note 39 supra.

41. "It is clear. . . that, even though the property has been delivered to a trustee, and vested remainders given to the bneficiaries, if the donor himself continues as beneficiary until his death ... the interest of the reminderman does not take effect until the donor's death and is, therefore, subject to the transfer inheritance tax." Glosser Trust, $355 \mathrm{~Pa} .210,215,48$ A.2d 401, 404 (1946) (emphasis added).

42. Borsch Estate, $362 \mathrm{~Pa}$. 581, 67 A.2d 119 (1949); see Bonsall Estate, 65 D. \& C. $251,266-270(\mathrm{~Pa} .1948)$.

43. See 98 U. of Pa. L. Rev. 249 (1949).

44. Crawford Estate, $362 \mathrm{~Pa} .458,67$ A.2d 124 (1949) (the Act in question would have altered the existing rule on apportionment of income between life tenant and remainderman).

45. For a full discussion, see Smith, Retroactive Laws and Vested Rights, 5 Tex. L. REv. 231 (1927), 6 TEx. L. Rev. 409 (1928); Smead, The Rule Against Retroactive Legislation: A Basic Principle of Jurisprudence, 20 MrNN. L. REv. 775 (1936). 
interests in the land objected to the sale. ${ }^{46}$ In such cases the vested interest is not deemed disturbed. The "property right" of the beneficiary affected by the 1949 act is no more than a right in rules governing the administration of the trust. It is submitted that the retroactive application of such changes as the majority control by the trustees, the power to sell the res, the power of the court to grant an option to sell, and the other changes in administration made applicable to revocable, but not irrevocable, trusts, do not deprive the beneficiary of a vested right. None of these changes allow property to be taken from $A$ and given to $B$, and they are little more than procedural changes in the administration of trusts.

A similar determination must be made with regard to the vested right of the settlor, and it is at this point that the scheme of the Effective Date section of the present Act becomes most apparent and should serve to distinguish it from other retroactive legislation. In each of the sections, save one, ${ }^{47}$ the words "unless otherwise provided by the trust instrument" are employed. The impact of this provision is that the settlor can otherwise provide if he so desires. Clearly, in testamentary and irrevocable trusts the settlor has no power to change the trust terms. Hence, if it was his wish in bestowing his property that there should be unanimous trustee action, and the applicable law is subsequently changed, the trust so administered would be retroactively altered by Section 949.48 In a revocable trust, however, if the settlor has the right to modify as well as to revoke ${ }^{49}$ any objections he might have to the administrative changes here imposed can be removed by exercise of the power of revocation. This distinction, it is submitted, should be very persuasive in a decision determining the constitutionality of this Act. To give this distinction legal effect, however, will entail the repudiation of some of the language heretofore employed by the court in defining the nature of a power of revocation. It has been said that the settlor has the sole control of the power and until it is exercised, it is to be treated as non-existent. ${ }^{50}$ The retroactive application of

46. Jefferies' Estate, 37 Lanc. 435 ( $\mathrm{Pa} .1921$ ). But see Van Voorhis Estate, 355 Pa. 82, 49 A.2d 257 (1946).

47. $\S 963$ is effective even when expressly directed otherwise by the settlor. It is believed that the section, insofar as it gives the power to grant an option to sell, which is the part which is involved in $\$ 105$, is not a sufficient change of existing law to subject it to constitutional attack.

48. "\$949... (a) Decision of Majority. If a dispute shall arise among trustees, the decision of the majority shall control unless otherwise provided in the trust instrument. . . ."

49. The Restatement of Trusts $\$ 331$, Comment $g$, states that ordinarily "a general power to revoke the trust will be interpreted as authorizing the settlor not only to revoke ... . but also to modify. . . The question has not, however, been decided by any Pennsylvania case found by the writer.

50. "But the right to revoke, unexercised, is a dead thing. Its presence in a deed does not alter the character of the instrument or estate granted; to all intents and purposes title and possession pass just as effectively as any deed or grant could make it, continuing in that state so long as the power of revocation lies dormant." Dolan's Estate, $279 \mathrm{~Pa}$. 582, 589, 124 At1. 176, 178 (1924). "The power of revocation reserved in the deed, having never been exercised, was precisely as if it had never existed." Lines v. Lines, 142 Pa. 149, 167, 21 At1. 809, 810, 811 (1891). 
the Act will force him to exercise his right to modify or suffer a change in the administrative requirements of the trust. It is submitted, however, that no great harm will result from taking cognizance of the unexercised power for the purpose of upholding the constitutionality of Section 105 of this Act. The power of modification should be sufficient to save the Act from impairing the settlor's vested interest. ${ }^{51}$

If, however, the Pennsylvania court should hold that the power to revoke does not include the power to modify, the suggested distinction is of less validity. If the settlor is forced to effect a conveyance to himself and then back again to the trustees, merely to insert clauses in the trust instrument avoiding the changes imposed by the statute, the effect upon his vested interest could be a severe and costly one. It must be noted, also, that even if the power to revoke includes the power to modify, there are considerations which might lead the court, in a given case, to find Section 105 unconstitutional. A case might well arise where a settlor, ignorant of both the Act and the handling of the trust estate by the trustees, finds that the trustees relying on Section 105 have by majority vote sold the res of the trust. If such a fait accompli cannot be altered by exercise of the power of revocation, a court might held that in such a case the application of Section 105 to a revocable trust resulted in a deprivation of a vested right. The customary talk about an unexercised power of revocation being tantamount to no power would then have special meaning.

There remains another interest which must be considered in this regard. Does the trustee have a vested interest which cannot be retroactively impaired? It has been held in Pennsylvania that a trustee himself has a vested right when appointed by testator's will and that in addition he is the guardian of the vested rights of the beneficiaries and that these rights cannot be swept away without due process of law..$^{52}$ Other Pennsylvania cases have held that for.some purposes a trustee has no such rights.53 Does a minority trustee of a revocable trust created prior to the act have a property right in the law of unanimity which is taken away by the provision for majority control? Whether or not the Pennsylvania cases are interpreted as dictating an affirmative answer, other jurisdictions most

51. There is some precedent to be found for this position in cases dealing with the retroactivity of the inheritance tax statute. See Commonwealth v. Linderman's Estate, 340 Pa. 289, 291, 17 A.2d 397, 399 (1940) ; Denniston's Estate, 325 Pa. 453, 191 At1. 39 (1937).

52. Brown v. Hummel, $6 \mathrm{~Pa} .86$ (1847) ; see Ervine's Appeal, $16 \mathrm{~Pa} .256$ (1851) (executor is said to have an inviolable interest which cannot be retroactively impaired).

53. See, e.g., Canovaro v. Brothers of Order of Hermits of St. Augustine, 326 Pa. 76, 191 Atl. 140 (1937) (statute making Church property subject to control of members as trustees gave no vested right to trustees which would be impaired by subsequent statutory change), In re Freeman's Estate, $181 \mathrm{~Pa} .405,37$ Atl. 591 (1897) (statute authorizing sales of trust property where trustees unreasonably withhold consent is constitutional). See also cases in which a trustee is held to have no right to appeal: In re Derbyshire's Estate, 306 Pa. 278, 159 At1. 439 (1932), In re Behringer's Estate, 265 Pa. 111, 108 Atl. 414 (1919). 
vehemently declare he does not. ${ }^{54}$ It is submitted that this problem might also be met with emphasis upon the settlor's power to modify the revocable trust. Again, however, it should be pointed out that the court could very well find that the power of revocation, unexercised, is of no consequence, and hence, treat a revocable trust precisely as though it were irrevocable for the purpose of determining vested interests.

If the court should so find, then the distinction made by the committee would be rendered useless. Precisely the same risk of interfering with vested rights would be encountered if applied to all types of trusts. It would seem that if the power to revoke is of no effect, then the interests involved in each type of trust would be of the same quality. The result, under those conditions, must be either that the committee was overly cautious, and need not have excepted any of the sections, or, that they were not sufficiently cautious, resulting in the unconstitutionality of the Act in so far as it applies retroactively to revocable trusts. ${ }^{55}$

\section{Marketability of Title}

The purported assimilation of realty and personalty in decedents' estates has its most significant impact on the transfer of decedents' real estate. The following two parts of this article deal respectively with the inevitably conflicting interests of the recipient of such property on the one hand, and of decedents' creditors on the other, which interests are affected by the same provisions of the Act. A comparison with the 1917 Act demonstrates the attempted solution of the traditional problems, but the solution has resulted in the creation of new problems.

\section{Marketability UNDER THE 1917 ACT}

A brief résumé of marketability under the old Act can be made by considering proposed sales of real estate by:

An heir or devisee. The purchaser of property from an heir took it subject to several risks. All debts of the decedent were liens on his real property for a period of one year from death, and remained liens for a five year period if the creditor indexed his claim within the initial year. ${ }^{56}$ There was always the possibility of a later will turning up, ${ }^{57}$ or of attacks

54. In re North Jersey Title Ins. Co., 120 N.J. Eq. 148, 184 Atl. 420 (1936); Metcalfe v. Union Trust Co. of N.Y., 181 N.X. 39, 73 N.E. 498 (1905).

55. The constitutionality of the entire Act is not called into question by the present discussion. It seems clear that $\S 105$ is severable from the remander of the Act within the meaning of PA. STAT. ANN., tit. 46, $\$ 555$ (Purdon, 1950), which provides for severing the unconstitiutional portions without defeating the entire act.

56. Act of $1917, \S 521$. Indexing a claim is accomplished by filing an action against the personal representative of the decedent. Szusta v. Krawiec, 36 Luz. L. Reg. 183 ( $\mathrm{Pa}$. 1943). It should be noticed that under this section the action which was indexed had to be prosecuted to judgment. But allowance of the claim by the Orphans' Court or inclusion of it in the Schedule of Distribution was the same as entry of judgment under this section.

57. Subsequent wills can defeat the title of purchasers from heirs only if probated within three years of decedent's death. PA. Star. AnN., tit. 20, $\$ 1887$ (Purdon, 1950). 
on the title by other people claiming to be heirs. This was possible as there could be no court order, in the absence of litigation, to confirm the distribution of real property. The possibility of later claims by heirs constituted a cloud on the title for thirty-one years, the period of adverse possession plus disabilities, ${ }^{58}$ unless a will was probated. A purchaser from a devisee was free of all claims, except the indexed ciaims of creditors, after two years from the probate of the will. ${ }^{\text {g日 }}$

$A$ personal representative by court order. ${ }^{60}$ This procedure was possible only if it was necessary to sell the realty to satisfy debts of the decedent. The purchaser under a sale of this nature would get title discharged of all liens except mortgages, the sale having the effect of a judicial sale. ${ }^{61}$

A personal representative under a iestamentary power given in the will. ${ }^{22}$ Where the will directed the executor to sell the real estate, an equitable conversion was worked which freed the land from the lien of debts mentioned above. ${ }^{63}$ If the will had merely authorized the executor to sell realty, there was no equitable conversion but the lien of debts was likewise negated because it was conclusively presumed that sales under such authority were for the payment of debts. ${ }^{63 a}$ Any purchaser from a personal representative under a testamentary power was subject to liens of record, ${ }^{64}$ and possibly to later claims by heirs or devisees. ${ }^{65}$

It seems that under the old Act, in the absence of a sale by court order, or possibly a sale under a testamentary power, the title to land was completely inalienable for one year after the decedent's death due to the lien of debts, and not totally certain until the expiration of the period of adverse possession since there was no formal administration of the realty under the auspices of the Orphans' Court.

\section{Marketability UNDER the New ACt}

One of the prime purposes of the Fiduciaries' Act of 1949 is to make real estate more readily alienable. ${ }^{68}$ To see how successful the legislators were in effectuating this purpose, an examination of the two methods of disposing of a decedent's estate will be made.

58. Pa. Stat. AnN., tit. 12, $§ 72,73$ (Purdon, 1931). PA. Stat. ANn., tit. 20, \$111 (Purdon, 1950), amending PA. STAт. ANN., tit. 20, \$112 (Purdon, 1931) provided a means for the surviving spouse to get absolute title in the Orphans' Court after a year from decedent's death.

59. See note 8 supra and text.

60 . Act of $1917, \S 551$.

61. Act of $1917, \S 574$.

62. Act of $1917, \S 711$.

63. Mahoney's Estate, 356 Pa. 358, 52 A.2d 328 (1947) ; Suppes's Estate, 322 Pa. 385, 185 Atl. 616 (1936).

63a. See Shaffer Estate, 360 Pa. 390, 61 A.2d 872 (1948).

64. See Fisher v. Kurtz, $28 \mathrm{~Pa} .47$ (1857).

65. Act of $1917, \S 711$ seems to indicate that an executor with anthority to sell under a will should be treated as an ordinary devisee.

66. See Hunter, Report of Proceedings of the Pennsylvania Bar Association IN INStitute on Fiduciaries ACt of 1949, 4. (Hereinafter cited as Report.) 
Administration by a Personal Representative. For the first time in the history of Pennsylvania, realty may be administered by the personal representative just as personalty. ${ }^{67}$ Although title to land still passes to the decedent's heirs or devisees, ${ }^{88}$ it is subject to several powers of the personal representative. Section 501 gives him power to possess all real estate except where an heir or devisee is in possession at the decedent's death; Section 541 gives the personal representative power to sell all real estate not specifically devised, unless he is otherwise prohibited in the will; Section 732 gives him the power to distribute the land before a formal accounting.

Court decree confirming distribution. If the personal representative goes through the formal administration provided for in the Act, the distributees of real estate are assured of absolute title. ${ }^{69}$ Briefly, the procedural steps involved in a formal administration, from the point of view of time consumption are: (1) an advertisement of letters; (2) minimum waiting period of six months before a personal representative can file his account; ${ }^{70}$ (3) notice of the filing and proposed audit to all interested parties ; ${ }^{71}$ (4) audit of the account and court approval of cistribution; ${ }^{72}$ (5) recordation of the decree awarding the real estate. ${ }^{73}$

Thus under the present Act it is possible for the heir or devisee to be assured of the status of his title after six or seven months as compared with the situation under the 1917 Act where an heir was sometimes never sure until the period of adverse possession had run, ${ }^{74}$ and a devisee was not assured of clear title until two years after probate of the will.

If there had been defects in the administration by the personal representative, but the court, nevertheless, decreed the distribution in accordance with his account, the title of the distributees would still not be adversely affected, although Section 721 allows five years for any party in interest to contest the decree. ${ }^{75}$

Sale during the administration by personal representative. Among the broad powers given to the personal representative is the power to sell all land not specifically devised or otherwise prohibited from sale by the will. ${ }^{76}$ This power to sell realty is similar to the power he had under the 1917 Act

67. $\$ 401$.

68. $\$ 104$.

69. There is no section that so states except $\$ 721$ by negative implication. $\$ 731$ provides for the distribution of estates not exceeding $\$ 1000$ without a formal account, and this distribution is also final.

70. $\$ 701$.

71. $\$ 703$.

72. The approximate period that the Philadelphia Orphans' Court requires is two weeks.

73. $\S 736$.

74. See note 58 supra.

75. Judge Hunter suggests, however, that if there is no advertisement of the grant of letters to a personal representative, a court cannot decree a distribution of real estate, and if done nonetheless, the title to such realty will be adversely affected. See note 66 supra.

76. § 541 . 
to sell personalty. The personal representative, however, must enter additional security if he desires to receive the proceeds of such a sale, unless he is exempt from giving bond at all. 77 The purchaser securing title from the personal representative via Section 541 receives it "discharged from the lien of legacies, from liability for all debts and obligations of the decedent, from liabilities incident to the administration of the decedent's estate and from all claims of distributees and persons claiming in their right," except liens of record. ${ }^{78}$ Although the Act does not so provide, the Philadelphia Orphan's Court has adopted a local rule requiring personal representatives who have entered bond to notify all parties in interest of the receipt of the proceeds of the sale. ${ }^{79}$ In the event that the land has been specificaily devised or has otherwise been prohibited from sale by the will, and the personal representative deems it advisable to sell the land, he may obtain an order of court directing the sale. ${ }^{80}$ Such an order would free the land of all claims, and also of liens of record except mortgages, since the sale has the effect of a judicial sale. ${ }^{81}$

The force of these sections is startling when it is seen that real estate is now marketable by a personal representative immediately upon obtaining letters if the personal representative need not enter security for the sale. If security is required, theoretically, the receipt of the proceeds of the sale need only be delayed for a period sufficient to allow the personal representative to enter such security and give notice to parties in interest. ${ }^{82}$

Sale during the administration by herrs and devisees. The heirs and devisees cannot convey good title before contirmation of the personal representative's account by the court, although legal title passes to them under Section 104 of the Act, because their title is subject to all the powers of the personal representative including the power to possess and sell. In order to make their title marketable the heirs and devisees must petition the court under Section 756 for a decree confirming their title. This can only be granted six years after the death of the decedent if a personal representative has been appointed and has not filed his account, or after one year if no personal representative has been appointed. ${ }^{83}$ Title, after a three month waiting period, during which time creditors can object to the decree, is free of all decedent's debts and subsequent wills, but is still subject to liens

77. $\$ 323$ exempts corporate personal representative, resident executors and nonresident executors, in certain instances.

78. $\S 547$.

79. Adopted April 4, 1950.

80. $\S 543$.

81. $\$ 547$. This section states that sales under court order shall be discharged from "liens of record at the time of the decedent's death." (Emphasis added). By a literal interpretation of the language in this sction, liens of record obtained after the decedent's death, but before the sale of realty, are not discharged. This interpretation is reinforced by the language used in $\$ 756$, "free of all decedent's debts not then liens of record," indicating that those drafting the Act intended to distinguish the situations.

82. See note 79 supra. See also $\$ 545$.

83. Note that the heirs or devisees can also obtain possession of realty under $\S 735$, subject to divestment, before a final decree of distribution. 
of record and possibly to claims from those subsequently alleging to be heirs. ${ }^{84}$

It should be noted that, inasmuch as the personal representative has no power to sell specifically devised property without court order, and hasn't the right to possess land occupied by an heir or devisee, the title of a specific devisee in possession is apparently free from any immediate powers of the personal representative. But, if the specific devisee in possession conveys, he passes title that is still subject to sale by an order of the court under Section 543 on petition by the personal representative. If the personal representative joins in a conveyance with the specific devisee, however, the purchaser would probably take the same title as if he had purchased the land directly from the personal representative under Section $541 .^{85}$

Distribution of realty before court decree. Section 732 gives the personal representative the right to distribute real estate at his own risk without filing an account. If he does this after one year has elapsed from the granting of letters, and no notice of claims has been given him, the heirs or devisees will take title free and clear of all but recorded liens. If the personal representative distributes in spite of notice given him within the year, although the ditributees' title is subject to creditors' claims, a bona fide purchaser from the distributees would probably take the land free of such claims. ${ }^{86}$ However, if the recipient was not the rightful distributee, both the recipient and any purchaser from him would be subject to the claims of the rightful distributee.

No administration by a personal representative. Statistics show that there is only one administration for every four deaths. This is logically explained in the light of the fact that the size of the majority of estates is less than $\$ 5,000.00-28.2 \%$ less than $\$ 1,000.00$ - thus not warranting the expense of a formal administration. 87

Sale by an heir or devisee within one year of decedent's death. How does the Act affect marketability where there is no personal representative appointed? Where no letters have been granted to a personal representa-

84. $\$ 756$ probably was intended to free the land of all but recorded liens, but the language used, "free of all decedent's debts not then liens of record, and regardless of the provisions of any testamentary writing of the decedent thereafter probated," may lead to the conclusion then that the land is subject to attack from heirs. This is to be compared with the language used in the Intestate Act of 1947. PA. Stat. AnN., tit. 20, 11.11 (Purdon, 1950) and the Intestate Act of 1917, PA. STAT. ANs., tit. 20, $\$ 112$ (Purdon, 1930) which clearly eliminates claims of the heirs and devisees.

85. See Schmidt, Report, op. cit. supra note 66, at 8; LAdnER, Real Estate CoNVEYANCING 139 (Supp. 1951).

86. See Schmidt, REPORT, op. cit. supra note 66 , at 9 . This assumes that the traditional creditor's lien no longer exists under the Act. The Act does not specifically abolish the lien, but provides other remedies in all other cases where the lien formerly extended. It is probably safe to assume that where no remedy is provided, none was intended, since that is the view of the Commissioners at least with regard to $\$ 732$. Sections 545,615 , etc., talk about "holders of a lien," but it is probable that this refers to liens of record.

87. See Schmidt, id. at 1. 
tive the same factual situation is presented under the Act of 1949 as where there was a formal administration under the Act of 1917, in the sense that the decedent's real estate is not administered by a personal representative in either case. The consequences in terms of marketability is likewise identical in that the property, under either Act, is not freely alienable until the expiration of one year from death, but the reasons for this period of inalienability are different under the old and new Acts. Under the old Act the land was inalienable because all debts of the decedent were liens on his real estate for one year after death; ${ }^{88}$ under the new Act, according to Section 615 , debts are not liens on the property, but a creditor can defeat any conveyance by an heir or devisee within one year of decedent's death by having a personal representative appointed.80

Sale by heir or devisee after one year from decedent's death. Land was more readily alienable after one year under the old Act than under the new Act where no personal representative has been appointed because the failure of a creditor to index his lien within the one year provided by the old Act was absolutely fatal to his claim against the real property; ${ }^{90}$ whereas, under the present Act he can retain a claim against all property not yet sold if he has a personal representative appointed after one year. ${ }^{91}$ Even if the land is sold after one year and before a personal representative is appointed, the creditor, whose claim is not barred by the statute of limitations, could apparently get another shot at the property if unknown heirs or devisees should later appear. This is so because Section 615 bars only claims against purchasers who acquired their interests from "those entitled to the property by will or by intestacy. . . ." 82

A purchaser from an heir or devisee has the further problem under the present Act of ascertaining whether or not a personal representative has been appointed. Although Section 301 of the 1949 Act provides that letters testamentary or of administration shall be granted only in the county where the decedent had his last principal residence, it might be very difficult for a purchaser to determine where that "residence" is, in order to see whether letters have been taken out there.93

It should be noted that Section 615 of the 1949 Act when applicable only frees the land from the claims of creditors; it does not purport to cut off the rights of those who might subsequently claim to be heirs or devisees and presumably such claimants have the same rights now where there is no formal administration as they did before when real estate was never administered.

Unquestionably, where a personal representative is appointed under the Act of 1949 , title to real estate which he administers is more readily

88. Act of $1917, \$ 521$.

89. $\S 305$ (b) (4) permits a creditor to administer the estate; he can take out

90. Act of 1917, § 521. Graham's Estate, 346 Pa. 497, 31 A.2d 125 (1943).

letters 7 days after the decedent's death $(\$ 305(\mathrm{c}))$.

91. $\S 615(1)$.

92. Emphasis added.

93. See Schmidt, REPORT, op. cit. supra note 66 , at 17. 
marketable, by far, than was real estate under the Act of 1917 . Where no letters are granted, however, realty is no more marketable under the present Act than it was before; in fact it is probably less marketable. It is interesting to note that the changes in marketability that have been wrought by the Act of 1949 have not been reflected in the rates charged by title insurance companies in Philadelphia County.

\section{Creditors' Rights}

From an early date in Pennsylvania a decedent's creditors have had a lien on his real estate for the payment of debts. ${ }^{94}$ Originally this lien existed for an indefinite period, but through the years the time for which the lien would extend without the creditors taking steps to preserve it has been progressively shortened. ${ }^{95}$

Under the Fiduciaries Act of 1917 the creditor's lien on a decedent's real estate was lost one year from the decedent's death unless during that period the creditor brought suit against the personal representative and indexed the suit in the judgment index in the county in which the action was brought as well as in the county in which the land was situated. ${ }^{96}$ If this was not done and the land was later sold in payment of debts, the creditor had no right to share in the proceeds of the real estate nor could he go against the land itself. In such a situation all creditors would first share pro rata in the personalty and then the deficiencies of those who had preserved their liens would be made up out of the realty. ${ }^{97}$ In this way the diligent creditor was given an advantage over the unwary or uninformed creditor. But all too often a creditor's rights in the land were cut off at the expiration of a year merely because of the procedure which it was necessary for him to follow in order to preserve his lien.98

To afford the creditor protection, and also to give the decedent's real estate a more marketable title, the Fiduciaries Act of 1949 abolished the old lien of debts and provided that the administration of real estate should be similar to that of personalty. ${ }^{99}$ No longer is the creditor's interest in decedent's realty lost forever if he fails to follow the procedure of bringing suit and indexing his claim within the year. No time limit is now set after which the creditor automatically without more loses the right to be satisfied out of decedent's realty. As long as the creditor's claim has not been barred by the statute of limitations he may give written notice to the personal representative, assuming that one has been appointed, and this will have the effect of tolling the statute of limitations. ${ }^{100}$ This will entitle the

94. Remick, Pennsylvania Orphans' Court Practice $\$ 95$ (3rd ed., 1938); see also note 9 supra.

95. Ibid.

96. Act of 1917 , $\$ 521$.

97. Mason's Appeal, 89 Pa. 402 (1879). 196 (1950).

98. Eckert, The Pennsylvania Fiduciaries Act of 1949, 11 Piтt. L. Rev. 194. 99. Id. at 195, 196; Ladner, Real Estate Conveyancing 115 (Supp. 1951). 100. $\S 614(a)$. 
creditor to written notice of the filing of the account and its call for audit or confirmation. ${ }^{101}$ If the property has not been previously distributed the creditor is entitled to be satisfied out of both realty and personalty notwithstanding the fact that he did not give notice within a year of decedent's death. ${ }^{102}$

In these respects the position of the creditor has been strengthened, but in other respects it has been weakened. Because of the possibility of a prior distribution before he gives notice of his claim it is now incumbent on the creditor to act more swiftly. For he is no longer guaranteed a lien on the realty for a period extending a year from decedent's death. An account may be filed six months after the grant of letters. ${ }^{103}$ If the creditor fails to present his claim at the audit or confirmation of that account he is not entitled to share in any of the realty or personalty distributed pursuant thereto. ${ }^{104}$ Thus if the account is filed in the minimum time and the audit follows soon thereafter, the creditor may lose his right in the real estate distributed at that time although a year has not passed since decedent's death. And even if the mechanics of administration proceed at a slower pace it is still necessary for the creditor to act quickly in order to preserve his interest in the realty. If he fails to give notice of his claim to the personal representative within a year of the grant of letters, at the expiration of that period the personal representative may distribute the decedent's property both real and personal, and neither the distributee nor the personal representative will be liable to the creditor for the property so distributed..$^{105}$ All of the creditor's interest in the real estate will then be lost.

A creditor may also lose his right to satisfaction out of the realty even though no personal representative has been appointed. At the end of a year from the decedent's death the heir or devisee or anyone claiming an interest through them may petition the Orphans' Court to establish title in them. ${ }^{106}$ The court may enter a decree nisi to that effect, and if no exception is taken within three months it will become absolute. ${ }^{107}$ The creditor will then have no more rights to that land.

The creditor may lose his rights to the land even though there is no court action, for if no letters have been granted within a year the bona fide grantee of an heir or devisee will take title free of all claims which were not liens or charges on the real estate at the decedent's death. But this is no more than happened automatically at the end of a year under the 1917 Act, whether or not a personal representative was appointed, if the creditor had taken no action. In such a case under the 1949 Act the position of the creditor has been improved in that he may still recover from the heir or devisee the value of the property through an action brought by a subse-

101. $\$ 703$.

102. See $\$ 616$.

103. $\$ 701$.

104. $\$ 616$.

105. $\$ 732$; Comment to $\$ 732$.

106. $\$ 756$.

107. Ibid. 
quently appointed personal representative, ${ }^{108}$ provided, of course, that such a person is not judgment-proof.

Assuming that the creditor has been diligent and taken all the necessary steps to protect his interest in the land before an accounting or call for audit, how does his protection under the Fiduciaries Act of 1949 compare with that afforded by the Fiduciaries Act of 1917? Under the old Act if the creditor had brought suit and properly indexed his claim a lien on the land existed for five years which could only be discharged by payment of the debt or by a sale undertaken to satisfy debts which were liens on the land. ${ }^{109}$ Such sale was conducted under the direction of the court and had the effect of a judicial sale. ${ }^{110}$ The personal representative making the sale was required to post bond. ${ }^{111}$ Under the Fiduciaries Act of 1949, however, the personal representative may sell decedent's real estate without making any petition to the court unless the land was specifically devised or the power was denied him in the will.112 In such a sale the title of the purchaser is free of all obligations to creditors except those which were liens of record at the decedent's death. ${ }^{113}$ It is true that, in order to receive the proceeds of such a sale, the personal representative must have given additional security if he was originally required to post bond, unless excused by the court, ${ }^{114}$ but there are many instances, aside from exceptions granted by the court, where a bond is not required.115 The result is that the creditor may no longer be secured by an interest in realty, a bond, or a sale conducted under the direction of the court, but will be left with a mere right to share in liquid assets which may easily be wrongfully disposed of by an unscrupulous personal representative. Moreover, the danger that an improvident sale may be entered into which would harm the creditor's interest in the estate by reducing the total value of the assets available to him is increased. Some protection is afforded against this danger by Section 545, which allows a party in interest to petition the court to restrain a sale of realty if it does not appear to be in the best interests of the estate, but just as in the 1917 Act this remedy is not available if the power of sale was given in the will, 116 and the right is of no avail to a creditor who has no notice of the sale, which may well be the case if the sale takes place early in the administration of the estate. ${ }^{117}$ Of course, with an honest and capable personal representative, this power of sale would not work to the detriment of the creditor and might well be to his advantage, as the personal representative could act quickly in making beneficial sales.

108. $\S 615$.

109. Act of 1917, $\$ \$ 521,574$.

110. Act of 1917, \$ 574 .

111. Act of 1917 , $\$ 557$.

112. § 541 .

113. $\$ 547$.

114. $\$ 541$.

115. $\$ 323$.

116. $\$ 545$.

117. LADNER, op. cit. supra note 99, at 136 . 
There are dispositions which may be made of realty other than a sale by a personal representative. First of all, when no personal representative has been appointed the heir or devisee may dispose of the property without a conveyance from the personal representative. In such a case it seems clear that the land remains subject to the claims of the creditor even in the hands of a bona fide purchaser, for though title to the land passes to the heir or devisee it is subject to the powers of the personal representative so that the purchaser has not actually acquired a complete title.118 But if a personal representative having notice of the creditor's claim voluntarily distributes the land, may the creditor then go against the land in the hands of a bona fide purchaser from the distributee? Under the old Act if the creditor had preserved his lien, the land remained subject to the creditor's claim even in the hands of a bona fide purchaser. Under Section 732 of the 1949 Act, however, a creditor will lose all right in the land if the personal representative voluntarily distributes to an heir or devisee who subsequently disposes of the land to a bona fide purchaser, since there is no longer a lien of debts on the land and, unlike the conveyance by an heir or devisee without a distribution by the personal representative, it can no longer be said that the personal representative has any powers over lands conveyed to distributees. ${ }^{119}$ In such a case the creditor is left only with a cause of action against the personal representative, who may or may not have posted bond, and against the distributee. ${ }^{120}$

\section{Conclusion}

The rules governing the administration of decedents' realty outlined above reveal both the extent and the limitations of the assimilation of realty and personalty under the 1949 Act. The inclusion at many points of special rules for real property, such as Sections 541, 545, and 615, demonstrates that the assimilation is not complete. In the main, the changes worked by the Act in this area seem to favor the readier and more certain transfer of property to the recipients, at the expense of opportunities of creditors to assert their rights against the land. Modern business conditions underline the need for greater marketability of real property, and the growth in the alienability of land has brought with it the necessity that the power to alienate may be freely and speedily exercised. The gravitation of the business of handling decedents' estates to trust companies emphasizes the growing interrelation of business methods and needs in general with the business of dealing with real property.

\section{The Power to Restrain Sales of Realty}

As noted above, one of the major changes made by the new Act is the expanded powers of sale of realty given a personal representative.

118. $\$ 615$ (implication).

119. Schmidt, REPORT, op. cit. supra note 66 , at 9 . See notes 9 and 86 supra and text.

120. Ibid., \$732. 
Whereas under the 1917 Act he could sell realty only under a testamentary direction, or under a court order where funds were needed to pay the decedent's debts, ${ }^{121}$ Section 541 of the 1949 Act empowers him to sell any real property not specifically devised where there is no specific prohibition in the will. This power is limited by Section 545, under which the court may restrain such sales in its discretion. It is to be noted at the outset that the power to restrain applies only to such sales as the personal representative may make under Section 541 ; it does not apply to sales which the will authorizes the personal representative to make. ${ }^{122}$ In contrast to the 1917 Act, a fiduciary with a testamentary power to sell can now sell for purposes of easing distribution and administration, irrespective of the wishes of the heirs. ${ }^{123}$ Their only legal sanction to prevent abuse of this power is the possibility of surcharge for negligence or fraud. ${ }^{124}$ But the additional remedy of restraint of sale is available with respect to other sales of realty, and the primary problem raised thereby is the extent of the restraining power in view of the curious history of the power in Pennsylvania law.

The leading case of Orr's Estate, ${ }^{125}$ decided in 1925, laid down the rule that a fiduciary must repudiate a contract of sale upon receipt of a higher offer from a third party. Its full ramifications, as seen in later cases, made any contract of sale prima facie improvident where a subsequent substantially higher offer was received. ${ }^{126}$ The court promulgated the doctrine in order to protect decedents' estates from improvident sales of assets, and to secure more funds for the estate. Obviously violative of the concept of the sanctity of contracts, the rule had the effect of making fiduciaries' contracts risky and uncertain. Purchasers incurred the risk of having what they thought was a good and binding contract invalidated by a third party's tender of a higher offer. If the purchaser knew that he was dealing with a fiduciary, he had no cause of action against the fiduciary personally, ${ }^{127}$ or against the estate ${ }^{128}$ for damages for his loss of bargain. The estate itself

121. Act of $1917, \S 552 ; 1$ Remick, Pennsylvania Orphans' Court Practice 160 (1938).

122. Cf. $\S \S 541,544$; see also $\S 545$.

123. It was indicated by Commissioner Schmidt that it is still desirable for testators to give executors an express power to sell real estate, notwithstanding the powers given by $\$ 541$ to sell for ". . . a testamentary power to sell cannot be restrained under \$ 545." REPORT, op. cit. supra note 66 , at 8 (1950).

124. When questioned about unnecessary sale of real estate by fiduciaries to swell commissions, Commissioner Schmidt replied, "Under the old law, a representative could sell all of the stock in a corporation, although the heir or devisee might desire to take in kind in distribution. As I say, we have to face these problems in a very practical way." Id. at 18 . But in certain areas, i.e., sales under $\$ 541$, the power of restraint in $\$ 545$ might be useful in preventing such abuse.

125. $283 \mathrm{~Pa} .476,129$ Atl. 565 (1925).

126. Kane v. Girard Trust Co., 351 Pa. 191, 40 A.2d 466 (1945) ; Good v. Capital Bank \& Trust Co., 337 Pa. 353, 11 A.2d 489 (1940); McCullogh's Estate, 292 Pa. 177, 140 At1. 865 (1928) ; Hoerner v. Union Trust Co., 39 D. \& C. 680 (Pa. 1940); but c.f. Peter's Estate, 39 D. \& C. 596 (Pa. 1940).

127. Kargiatly v. Provident Trust Co., 338 Pa. 35812 A.2d 11 (1940).

128. Powers' Estate, 153 Pa. Super. 161, 33 A.2d 501 (1943). 
suffered too, because this doctrine discouraged purchasers from bidding on property being sold by a fiduciary, thus retarding liquidation of the estate and raising costs of administration. The temporary benefit from taking higher bids was thus outweighed by resulting decreases in the total amount received by the estate when a consummated sale took place. ${ }^{129}$ Further, ordinary concepts of equitable conversion on execution of contracts of sale, which put the risk of loss before settlement on purchasers, did not apply to sales made by fiduciaries, because of the rule in $O r r$ 's Estate. ${ }^{130}$ Thus, to protect the estate fully, the fiduciary had the burden of making proper insurance arrangements. A third group injured by the application of the rule were the real estate brokers, who were not entitled to any commission for their services where they knew they were dealing with a fiduciary if, prior to settlement, the contract was repudiated because of the receipt of a higher offer. ${ }^{131}$

Taking cognizance of dissatisfaction with the settled rule, ${ }^{132}$ the legislature, in 1945, enacted remedial legislation. ${ }^{133}$ The Act forbade a fiduciary from repudiating his contract on the grounds of inadequacy of consideration, or receipt of an offer to deal on other terms. Furthermore, a court could not refuse to grant specific performance for the same reasons. However, the right of the court to set aside a contract for fraud, accident or mistake, or to surcharge a fiduciary for negligence or bad faith was not interfered with. ${ }^{134}$ This Act was effective in abrogating the rule in Orr's Estate and in reinstating the efficacy of executory contracts of sale made with fiduciaries.

In light of the foregoing, a serious question arises as to whether the new Act resuscitates the rule in Orr's Estate, with regard to sales made by personal representatives other than under a testamentary power, or whether the courts will utilize the broad language of Section 545 to do so themselves. It is the contention of some experienced attorneys in the field, that Section 545 is not a return to the quagmire of Orr's Estate, ${ }^{135}$ even though there is no hint in the language of that section as to where a line should be drawn. Under certain types of situations the court should, and probably would, exercise its restraining power: where the property involved has sentimental value, and the heirs desire it to remain in the family, an unnecessary sale would be restrained; where a legatee desires to take his gift in the form of realty rather than money, an unnecessary

129. In re Central Trust \& Savings Co., 41 D. \& C. 304, 307 ( $\mathrm{Pa} .1941)$.

130. Brigham, Fiduciary Agreenents of Sale, 15 PA. B.A.Q. 221, 226 (1944).

131. Clark v. Provident Trust Co., 329 Pa. 421, 198 Atl. 36 (1938).

132. "We also suggest that the attention of the Legislature might well be called to the question of the advisability of changing by statute the effect of the decision in Orr's Estate and the cases which have followed it." Dissenting justices in Kane v. Girard Trust Co., supra note 126.

133. Pa. Stat. Ann., tit. 20, §§ 818, 819 (Purdon, 1950).

134. Ibid.

135. ". . there is no fear of the ghost of Orr's Appeal returning." Report, op. cit. supra note 66 , at 8 . 
sale would also be restrained. ${ }^{136}$ Further, if a bona fide dispute arises between an heir and the personal representative as to the wisdom of retaining real estate for investment purposes, and a sufficiently strong case is made out of a potential rise in its value as an investment, the sale might be restrained. Finally, there might arise a situation where an heir feels that a sale would be improvident, and can prove a reasonably wide divergence between the market value at the time of the contract, and the proposed contract price. This, too, might call for the application of Section 545. Restraining these sales as a matter of public policy would fall short of the rule in Orr's Estate, for even in the last situation mentioned above there is a marked distinction between requiring a fiduciary to sell at the then-existing market value and abrogating a contract of sale when the market rises and a higher offer is made.

Whatever the desirability of restricting the power to restrain sales, the question remains what the Orphans' Courts will do. That Orr's Estate is not revived is well supported not only by policy considerations but by the fact that the Act of 1945 is still on the books. ${ }^{137}$ On the other hand, the repealer section of the 1949 Act states that "all other acts and parts of acts inconsistent herewith are hereby repealed." 138 Whether it will be held that the restrictions imposed by the 1945 Act are inconsistent with the broad powers granted by the 1949 Act will depend on whether the Orphans' Courts have been sufficiently influenced by the arguments of the critics of Orr's Estate to impose a restriction upon themselves, or whether they will continue to handle fiduciary sales under the broad equitable powers traditionally utilized. It is to be noted that the 1949 Act has left to the discretion of the separate Orphans' Courts the procedures to be worked out in the exercise of the powers of restraint. The Philadelphia courts have adopted a rule requiring a fiduciary under bond to furnish the court, in a petition to receive the proceeds of a sale, complete information regarding the terms and conditions of the sale, the names of all interested parties, and proof that notice of the sale was given to such persons. The court then appoints its own appraiser to evaluate the property, and this appraisal is used by the court as an aid in determining whether to approve or disapprove the sale. ${ }^{139}$ This discretion as to procedures may be carried to the point of taking Section 545 at its face value, as a reiteration of the equitable principles inherent in Orphans' Courts' activity. In Orr's Estate the court based its decision entirely upon the ground that the acts of executors are subject to the control of the Orphans' Court, which has full power to protect the estate from an improvident contract. ${ }^{140}$ If this high statement is held to be the sense of

136. See note 124 supra. $\$ 734$ empowers the court to grant distribution in kind. It is arguable that this section would be meaningless unless the court could restrain the disposition of realty prior to distribution.

137. The new 1950 edition of Purdon includes the Act in $\$ \$ 818,819$.

138. $\$ 1401(\mathrm{~b})$.

139. Ladner, Real Estate Conveyancing 134-135 (Supp. 1951).

140. See Brigham, supra, note 130 at 222 
Section 545, that section may well be the initial step in the resurrection of Orr's Estate.

The only case to date that has dealt with Section 545 stated in dictum that each case will depend upon its particular facts. ${ }^{141}$ No mention was made of any restriction on the power to restrain; indeed the court took special note of the broad discretion granted by Section 545 . It is hoped that an interpretation of the power to restrain, when the issue arises, will be made not solely with regard to the language of the Act, but with an eye to the proper meaning of the Act in the light of the difficulties attendant on the rule in Orr's Estate, and the considered opinions of the commissioners.

\section{Order of Abatement}

Section 751(a) of the Fiduciaries Act of 1949 provides that where there is a deficiency of assets, ${ }^{142}$ after payment of creditors, to satisfy the claims of all distributees, and the testator has not dictated in his will a different scheme of abatement, gifts shall be preferred without distinction between real and personal estate in accordance with the following schedule:

(1) Specific gifts to, or in trust for, the surviving spouse.

(2) Specific gifts to, or in trust for, the decedent's issue.

(3) All other specific gifts, whether outright or in trust.

(4) General legacies of cash, stocks, or bonds.

(5) All other general gifts. (No indication is given in the Act or the comments as to the exact meaning of the phrase.)

(6) Residual gifts.

(7) Intestate property.

In so providing, the Act deals with the three primary difficulties historically associated with abatement. These are (a) the general order of abatement among the different classes of gifts; (b) preferential treatment of various categories of takers within any one class; and (c) effect upon abatement of the distinction traditionally made between gifts of personalty and gifts

141. See Diamandas Estate, 73 D. \& C. 334, 337 (Pa. 1950).

142. The Pennsylvania common law apparently drew no distinction between a deficency caused by debts exceeding the testator's anticipation, and one caused by the widow's electing to take against the will. Lonergan's Estate, $303 \mathrm{~Pa}$. 142, $154 \mathrm{Atl}$. 387 (1931) ; Gallagher's Appeal, 87 Pa. 200 (1878) ; Gallagher's Estate, $76 \mathrm{~Pa} .296$ (1874) ; contra: Taylor's Estate, 5 Phila. 218 (1863). On the other hand, New York, when the latter situation is presented, abates all legacies equally, the theory probably being that the testator did not contemplate the widow's electing to take against the will, and hence had no intention regarding abatement. In re Byrnes Estate, 149 Misc. 449, 267 N.Y. Supp. 627 (1933). There seems to be no Pennsylvania cases concerning the order of abatement when the deficiency is caused by the birth of a pretermitted child, but the general rule in other jurisdictions is that all legacies abate equally. Alexander, CoMmentaries on Wilis \$706 (1918). However, the normal rules of abatemient will be suspended even in Pennsylvania when the deficiency is caused by the waste of the executor, and all legacies abate equally. Strohm's Appeal, $23 \mathrm{~Pa} .351$ (1854). 
of land. In determining these problems, the Act has, in general outline, followed the rules of prior Pennsylvania law: but in certain specific details, it has departed from precedent.

The General Order of Abatement Among Classes of Gifts. In providing that intestate property and then residual, general, and specific gifts are abated in that order, the Act follows the rules of the common law based upon the presumed intention of the testator. ${ }^{143}$ One exception to the traditional pattern appears in clauses 4 and 5 of the present Act, which make a distinction between general gifts of money or money's worth in stocks or bonds, and general gifts of other property. Such a distinction was unknown in early times; and its origin, for which no valid reason or explanation has ever been advanced, is to be found in the Wills Act of 1917. It was there provided that pecuniary legacies should be payable out of real estate not specifically devised. ${ }^{144}$ The effect of this section was to place general pecuniary legacies in a status just below specific gifts and above all other non-specific bequests and devises, while non-pecuniary bequests were left in their traditional position. Wise or not, the distinction between general gifts of money and other property is now a confirmed idiosyncrasy of Pennsylvania law.

The Order of Preference Within Classes of Gifts. At common law, certain donees were preferred within classes, although their preference could not extend to advancing them at the expense of gifts in a higher class. ${ }^{145}$ Such preferred treatment was accorded creditors left gifts in lieu of their debts, ${ }^{146}$ widows, ${ }^{147}$ and minor children of the testator if the gift was for maintenance. ${ }^{148}$ The rationale for such preferences was drawn from two considerations. The first, especially applicable to the child's preference, ${ }^{149}$ was the presumed intent of the testator. The second was that creditors and widows could enforce claims against the estate and receive payment unabated in any event. ${ }^{150}$

143. Atkinson, Handbook of the Law of Wills at 708 (1937).

144. Pa. Stat. Ann., tit. 20, §241 (Purdon, 1930).

145. Boehrig's Estate, $17 \mathrm{~Pa}$. Dist. 46 (1907) (demonstrative legacy to the testator's brother was preferred to a pecuniary legacy to the testator's daughter). The conclusion is also borne out by the language in Appeal of the Trustees of the University of Pennsylvania, $97 \mathrm{~Pa}$. 187, 199-200 (1881): "But, if there be any valuable consideration for the testamentary gift, or the relinquishment of any right or interest, such legacy will be entitled to preference . . . over other general legacies which are mere bounties." Emphasis added. This was also said in effect in Henry's Estate, $20 \mathrm{~Pa}$. C.C. 415,418 (1898).

146. Harper's Appeal, 111 Pa. 243, 2 At1. 861 (1884); Appeal of the Trustees of the University of Pennsylvania, stipra; Wilson's Estate, 15 Phila. 528 (1882); Atkrnson, op. cit. supra note 143, at 709-710; AleXANDER, op. cit. supra note 142, at 697 . (1890).

147. Reed v. Reed, 9 Watts 263 ( $\mathrm{Pa} .1840$ ) ; McDaniel's Estate, 20 Phila. 86

148. Boehrig's Estate, supra note 145 ; Bixenstein's Estate, 6 Pa. Dist. 19 (1896); Barry's Estate, 13 Phila. 310 (1880) ; Reed v. Reed, stipra.

149. Reed v. Reed, supra; Barry's Estate, supra; Bixenstein's Estate, supra; Comment, 36 Mich. L. Rev. 297, 305-306 (1937).

150. Comment, supra note 149 at $298-302$. 
This common law system of preferences within classes has been adopted to an indeterminable extent by the present Act. Clauses 1 and 2 provide preferential treatment for specific gifts to spouses and children. The creditor preference, however, is nowhere mentioned. This suggests that the legislature intended to abolish the creditor's preference entirely. However, since no such intent is specifically expressed, it is possible that the courts will read a preference for creditors into the general framework of clauses 3,4 , and 5. This would help to cut down on the litigation of unliquidated claims which the creditor preference primarily served to prevent; for one effect of a literal reading of the Act is that creditors, when abatement threatens, may well sue the estate.

Clauses 1,2 and 3 effect additional minor changes. No cases have been found in which the question of a widower's preference has been raised, but clause 1 specifically provides for it by the use of the word "spouse." Clauses 1 and 2 place the claim of the surviving spouse ahead of the issue's, whereas the Pennsylvania common law apparently placed them on a parity. ${ }^{151}$ Lastly, no longer must the dual common law requirements of minority and maintenance be fulfilled before a child's preference is granted. ${ }^{152}$

One question, not expressly settled by the Act, is the extent of the surviving spouse's preference. Is the spouse's specific legacy in excess of the statutory share preferred to the extent of such excess? The answer depends upon the basic rationale ascribed to the preference. If the theory is the spouse's right to take unabated against the will, any excess should abate proportionately with all other gifts; if the basis is the presumed intent of the testator, the preference should cover the entire gift. Historically, it was created to "bribe" the widow from exercising her indefeasible right to dower, which could disrupt the scheme of every devise since the widow was entitled to her interest in the land itself. ${ }^{153}$ Analogizing to the position of the creditor, the courts called the widow a "purchaser." The preference thus justified, there was no need to seek a more valid justification since what theory was employed mattered only if the gift exceeded the statutory share, and the issue was not raised until 1920. The court in Greave's Estate, ${ }^{154}$ led astray by the "purchaser" talk in the long line of cases, ignored the possibility of there having always co-existed the more vital underlying basis of simply fulfilling the testator's presumed intent. This was openly recognized as the rationale for the child's preference, but unarticulated with reference to the spouse's because such an-

151. Sussman's Estate, 62 Mont. Co. L.R. 297 (1946) (both wife and daughter had specific legacies).

152. See note 148 supra. It seems perfectly clear upon a literal reading of the Act that these requirements have been eliminated, and yet to quote from the Commissioner's Comment, "Clauses (1) and (2) are intended to clarify the confusion which arises where a legacy is given to a widow or for maintenance of a child" (italics supplied). Do the Commissioners infer that there still remains this condition?

153. Atkinson, op. cit. supra note 143 , at 710 .

154. 29 PA. Dist. 577 (1920). 
nouncement was never necessary. In that case, the court held any excess of the statutory share abated. This single lower court decision cannot be accepted as the settled Pennsylvania law, and probably the legislative intent behind the Act was to follow the enlightened majority view of other jurisdictions which is to prefer the entire gift, ${ }^{155}$ Greave's Estate notwithstanding.

This conclusion is fortified by an analysis of the Act. That the creditor's preference is unmentioned, while the preferment for children is extended, suggests that the legislature was considering the presumed intention of the testator; for the former is founded exclusively upon the theory of purchase, and the latter is based exclusively upon the theory of the testator's intent. Moreover, the Act expressly states that the preference of the spouse is supreme. Unless the entire gift of the spouse is preferred, the order prescribed by the Act will be partially repudiated.

Curiously, and unfortunately, the Act limits all preferences to takers of specific property. No preference whatsoever is granted any takers of general legacies. It might be argued that every reason for preferring particular takers of specific property applies with equal force to takers of general property. It is possible that the courts will read into clauses 4 and 5 the same scheme of preferences set up specifically in clauses 1, 2, and 3 . Such action would seem to be legitimate since the Commissioner's Comment to Section 751 states that the sections are but declaratory of the existing case law.

The Effect Upon Abatement of the Distinction Between Personalty and Land. At the early English common law, gifts of personalty, whether specific, general, or residual abated before gifts of real estate or descended land. ${ }^{156}$ This preference, based upon the distinctive position of landed estate, has been completely abolished by the present Act. According to the Commissioners' Comment upon Section 751, this institution of parity between the two classes of estate is the most significant change made by the Act. For most practical purposes, however, the Pennsylvania law had already long ignored the distinction.

From the earliest times, specific devises, bequests, and legacies have abated pro-rata in Pennsylvania. ${ }^{157}$ That the British distinction was not enforced here is explained by the fact that since 1700 land has been subject to simple contract debts in this Commonwealth. ${ }^{158}$ Thus, the repudiation of the distinction between bequests and devises made in clauses 1,2 , and 3 is far from surprising, for it amounts to a mere reiteration of traditional Pennsylvania law.

155. Comment, supra note 149 , at 300-302.

156. Arkinson, op. cit. supra note 143 , at $\$ 251$.

157. Comm. v. Sheely, 13 S. \& R. 348 (Pa. 1825); Appeal of Armstrong, 63 Pa. 312 (1869).

158. Act of Nov. 27, 1700, 2 PA. Stat. L. 31-34 (Mitchell \& Flanders, 1896). This Act was repealed by the Queen in Council, Feb. 7, 1705-6, but its provisions were included in other legislation. For a discussion, see Graff v. Smith's Admr's, 1 Dall. 481 ( $\mathrm{Pa} .1789$ ). 
In the case of general gifts, however, the story is somewhat different. That general devises were also subject to debts was judicially ignored. Instead, personalty was deemed to be the primary fund for the payment of debts and it was held throughout the course of the 19th century that general legacies and bequests would abate before general or residual devises or descended lands. ${ }^{159}$ This discrimination was somewhat ameliorated by cases holding that where land and personalty had been "blended" in the residual clause, ${ }^{160}$ or elsewhere, ${ }^{161}$ land would abate pro-rata with gifts of personalty of the same class and give way before personal gifts of a higher category. This illogical and confused state of the law was largely remedied by the Wills Act of 1917. Its provision that pecuniary bequests should be payable out of land not specifically devised ${ }^{102}$ meant that general pecuniary bequests were to be preferred above general devises. However, the status of other general bequests remained unchanged. Until the present Act was passed, it was true that general bequests and gifts of personalty in residual clauses would give way before general or residual devises or descended lands, "blending" always excepted. With the passage of this Act, these last vestiges of the realty preference have been swept away. This abolition of the realty preference, when coupled with the preference given to pecuniary legacies under clause 4 , leads to an unprecedented result. Perhaps for the first time in the history of Anglo-American law, there is a jurisdiction in which non-pecuniary as well as pecuniary gifts of personalty are in practice preferred over gifts of land. The commissioners, instead of eliminating the distinction as they claim, have in fact partly reversed it.

Demonstrative Legacies. Section 751(b) of the Act provides that "property out of which a demonstrative legacy is primarily to be paid shall be deemed $t c$ be specifically devised or bequeathed to the extent of such demonstrative legacy." The natural implication of this language is that general property, out of which a deficiency in the fund is to be made up, is not to be deemed specifically, devised or bequeathed, a mere restatement of the common law. ${ }^{163}$ This means that where $T$ bequeaths " $\$ 10,000$, the sum I have on deposit at the First National Bank" to X, and there is but $\$ 8,000$ on deposit in that bank at the time of death, the $\$ 8,000$ in the bank will abate with the specific provisions while the $\$ 2,000$ which will be taken from the general estate to complete the legacy will abate with the general

159. Crone's Appeal, $103 \mathrm{~Pa} .571$ (1883) ; Risk's Appeal, $110 \mathrm{~Pa} .171,1$ Atl. 85 (1885); Espy's Estate, 207 Pa. 459, 56 At1. 1005 (1904).

160. Nicholas v. Postlethwaite, 2 Dall. 131 (Pa. 1791); Gallagher's Appeal, 48 Pa. 121 (1864).

161. Fetter's Estate, 152 Pa. Super. 10, 30 A.2d 647 (1943).

162. PA. Stat. AnN., tit. 20, $\$ 241$ (Purdon, 1930). The Wills Act of 1947 repeats the same provision save that it excepts pecuniary legacies of less than $\$ 100$. PA. Stat. Ann., tit. 20, $\$ 180(14)$, (13) (Purdon, 1950). This exception of legacies of less than $\$ 100$ may be repealed, in effect, by clause 4 of the present Act, which includes pecuniary legacies of less than $\$ 100$.

163. The common law view was that demonstrative legacies abated with specific gifts to the extent of the fund designated. ATKINSON, op. cit. supra note 143, at 711; 1 Roper, A Treatise on the Law of Legactes, 363 (4th ed., White, 1848). 
gifts. This ästinction has never been recognized in terms in Pennsylvania, and there are dicta indicating that demonstrative legacies will abate with specific legacies regardless of whether the fund designated is sufficient to cover them. ${ }^{164}$ The present Act corrects this possible aberration in Pennsylvania law.

\section{Foreign Fiduciaries}

According to common law doctrine, the power of a personal representative, or other court appointed fiduciary, was confined to the jurisdiction of the court which appointed him. ${ }^{165}$ This rule has been applied as between fiduciaries appointed in different states of the United States. ${ }^{166}$ As a result, whenever a decedent possessed property situated in more than one state it became necessary to raise ancillary administration in the other states in addition to the domiciliary administration. Debtors of the decedent who voluntarily paid a foreign personal representative subjected themselves to a possibility of double payment if an ancillary administration was later created. ${ }^{167}$ Recognition of the fact that in many cases the added expenses and delay of ancillary administration served no useful purpose has led to a relaxation of the strict common law rule through the doctrine of comity and by statute. ${ }^{168}$

One of the first states to grant extensive powers to foreign fiduciaries was Pennsylvania which in the Act of 1705 gave a foreign fiduciary all the rights and powers accorded to local fiduciaries. ${ }^{169}$ This liberal approach was abruptly reversed in 1830 when Chief Justice Gibson completely ignored the 1705 Act and reiterated the common law view. ${ }^{170}$ His views were incorporated into the 1832 Act, ${ }^{171}$ which terminated all the powers of a foreign fiduciary unless ancillary administration was raised. Except for some minor amendments ${ }^{172}$ foreign fiduciaries remained powerless in Pennsylvania until the Fiduciaries Act of 1917. The ostensible approach of the 1917 Act was to limit strictly the activities of foreign fiduciaries, but

164. See: Wilson's Estate, 260 Pa. 407, 410, 130 Atl. 880, 881 (1918); Walls v. Stewart, $16 \mathrm{~Pa} .275,281$ (1851).

165. Tourton v. Flower, 3 P. Wms. 369, 24 Eng. Rep. 1105 (1735) ; Stacy v. Thrasher, 6 How. 44 (U. S. 1848).

166. Johnson v. Powers, 139 U.S. 156 (1891) ; Robinson v. First National Bank, 45 F.2d 613 (1930).

167. These problems are discussed in Handbook of tHe National Conference of Commissioners On Uniform State Laws And Proceedings 320 (1944), in a preface to a proposed Uniform Powers of Foreign Representatives Act at page 325. This proposed Act has not been enacted in any state, although several provisions of Article XI of the '49 Act of Pennsylvania are derived from this proposal.

168. Reynolds v. McMullen, 55 Mich. 568, 22 N.W. 41 (1885); Kirkbride v. Van Note, 275 N.Y. 244, 9 N.E.2d 852 (1937); see comment, 7 BrookLYN L. REv. 247 (1937).

169. 2 Stat. At LARGe, Ch. 133, pp. 195-197 (1705). Its application to sister states was recognized in McCullough v. Young, 1 Binn. 63 (Pa. 1803).

170. Brodie v. Bickley, 2 Rawle 431 (Pa. 1830).

171. Act of March 15, 1832. tions).

172. Act of June 16, 1836 (exception made for stock of Pennsylvania corpora- 
enough exceptions were added so that in effect broad powers were granted. ${ }^{173}$ Thus, by the mere filing of an affidavit stating that the estate which he represented was not indebted to any Pennsylvania creditor, a foreign fiduciary could transfer, assign, and reecive the interest, on the following: any public debt of Pennsylvania or its political sub-divisions, debts of national banks situated in Pennsylvania and mortgages on real estate in Pennsylvania. ${ }^{174} \mathrm{He}$.could also issue scire facias on all judgments on which the decedent's creditor's lien was about to expire.175 If he was a testamentary trustee or personal representative, in addition to the affidavit regarding creditors, he had to file a certified copy of the will or his certificate of appointment, but he did not have to raise ancillary administration to exercise the above powers. ${ }^{176} \mathrm{He}$ had the right to sell real estate in Pennsylvania, when the decedent had specifically given that power in his will. ${ }^{177}$ By an amendment in 1937 these powers were enlarged so that upon the filing of the affidavit the foreign fiduciary was entitled to foreclose on a mortgage and to receive all moneys, goods, stocks, bonds and choses in action which were owned by the decedent. ${ }^{178}$

One crucial area remained in which it was necessary for the foreign fiduciary to raise ancillary administration. The Act failed to give the foreign fiduciary the right to sue in Pennsylvania courts to enforce the rights granted under the Act except in the case of foreclosing mortgages and reviving prior judgments. ${ }^{179}$ As a result a single recalcitrant debtor could virtually force ancillary administration thereby negating the entire purpose of the Act.180 Section 1101 of the Act of 1949 specifically remedies this defect by giving a foreign fiduciary the right to "institute proceedings in this commonwealth . . . and to exercise all other powers of a similar local fiduciary," provided only that he file an exemplified copy of his appointment, the will, and an affidavit stating after a diligent search he has found no creditors in Pennsylvania. ${ }^{131}$ When these two requirements are fulfilled a foreign fiduciary has the same power as a local fiduciary. 182

173. Act of 1917, $\$ \$ 991-1001$

174. Act of $1917, \S 991$.

175. Act of 1917 , $\$ 995$.

176. Ibid.

177. Act of $1917, \S 996$. This power could not be exercised until one year after the death of decedent.

178. P.L. 2758, § 1, 1937. Incorporated into $\$ 995$.

179. Act of $1917, \$ 997$.

180. Mansfield v. McFarland, $212 \mathrm{~Pa} .173,51$ Atl. 763 (1902) ; Elmer v. Hall 148 Pa. 345, 23 Ati. 971 (1892).

181. \$1101. A surprising practical result of the requirement of exemplified copies has been to make it more expensive to furnish the necessary proofs under the present Act than it was under the Act of 1917. In order to get an exemplified copy of the will or his appointment a foreign fiduciary must: (1) have the domiciliary Register of Wills certify that the copy is true and correct; (2) have a judge of the domiciliary equivalent of the Orphans' Court certify the Register's act; (3) have a clerk of the court certify the Judge's act. In gathering this triple hearsay the foreign fiduciary must pay a small fee at each stage. The results of this procedure are sometimes ludicrous, as in Camden county where the same official performs all three functions, and are always time-consuming since it is a rare foreign fiduciary who manages to tag all three bases the first trip around.

182. It is to be noted that the definition of "foreign fiduciary" does not include a non-resident fiduciary of a local estate. "( $\$ 101-7)$ None of the provisions of 
An outstanding feature of the 1949 Act is Section 1102 which permits a foreign fiduciary to transfer stock in a Pennsylvania corporation by merely submitting his certificate of appointment without complying with the other requirements of Section 1101. This provision has resulted in substantial savings in time and expense. During the last year, in the county of Philadelphia alone, foreign fiduciaries have been able to transfer stock in 2500 cases without making a search for creditors. ${ }^{183}$ Creditors can prevent the transfer of such assets only by exercising their right to force ancillary administration. ${ }^{184}$ The liberality of this section has been criticized on the grounds that the right to enforce ancillary administration affords no real protection since many creditors are ignorant of this power. Further, since the Act does not require the fiduciary to wait any particular period of time before exercising his powers under Section 1102, ${ }^{185}$ a diligent fiduciary might be able to remove the stock before the creditors could bring ancillary administration. As a result this section will frequently force the creditor to go to the domiciliary state to press his claim. The proponents of this section contend that the talk of protecting Pennsylvania creditors simply confuses the issue since the most "protection" Pennsylvania was able to afford creditors even when full ancillary administration was required in every case was tn save them the expense of going to the domiciliary jurisdiction to press their claims. ${ }^{186}$ The choice then is between

Article XI specifically covers this situation. The Act of 1917 provided that the court could in its discretion refuse to appoint as fiduciary of a local estate any nonresident of the Commonwealth, or could appoint a resident co-fiduciary to act in conjunction with any non-resident fiduciary. The present Act raises a question as to whether this practice will be continued. County.

183. Information obtained from the Register of Wills Office, Philadelphia

184. The present Act does not in terms give the Pennsylvania creditors the right to force ancillary administration but this right is implicit in the fact that none of the powers granted by $\$ 1101$ can be exercised if the fiduciary is unable to file an affidavit that there are no Pennsylvania creditors. See Commissioner's Comment to that section. In view of the consistent development of Pennsylvania case law to the effect that it is error to remit Pennsylvania creditors to the domiciliary jurisdiction where there are Pennsylvania assets (see note 186, infra) it would seem to follow that the right to force would extend to the case where the decedent's only asset in Pennsylvania is stock in Pennsylvania corporations as to which no affidavit is required.

185. The month waiting period required by $\$ 1101$ does not apply.

186. For obvious constitutional reasons no attempt has ever been made to give Pennsylvania creditors any priority over domiciliary creditors in assets located in Pennsylvania when the estate is insolvent. When there is ancillary administration the practice has been to adjudicate and distribute the claims of Pennsylvania creditors in Pennsylvania if the estate is solvent, remitting the balance to the domiciliary jurisdiction. Where the estate is insolvent, the practice has been to adjudicate Pennsylvania claims here but to suspend payment until informed how much of the Pennsylvania assets are needed by the domiciliary jurisdiction in order to afford an equitable distribution of all the decedent's assets among all of his creditors. In this connection see Hopkins Estate, 28 D. \& C. 431 (1936); Middlebury's Estate, 249 Pa. 203, 207, 94 At1. 820, 822 (1915); Dent's Appeal, 22 Pa. 514, 520 (1854): Well's Estate, $161 \mathrm{~Pa} .218,223,28$ At1. 1116, 1118 (1894). The net saving to the Pennsylvania creditor by ancillary administration, then, is that the creditor doesn't have to go to the domiciliary state to press his claim. This saving has been regarded as so important by the court that it has been held not to be within the court's discretion to remit Pennsylvania creditors to the domiciliary jurisdiction where there are assets in Pennsylvania, Hopkins Estate, supra. 
imposing on all foreign estates the expense and delay of making a search for creditors in order to save a few unwary creditors the expense of a trip to the domiciliary jurisdiction or simply permitting the fiduciaries to remove the assets upon submission of their certificate, letting the burden of his own unwariness fall upon the creditor who has failed to exercise his right to force ancillary administration. Since both of these arguments apply to all types of assets, the contrast between Section 1102 and the rest of Article XI may well be considered a compromise between the above two schools of thought. The proposed 1951 amendment to the '49 Act expands Section 1102 to include "stocks, bonds and other securities of a Pennsylvania corporation or of a federal corporation located in Pennsylvania," and makes a significant change in allowing the foreign fiduciary to receive dividends thereon. ${ }^{187}$

The contrast between Section 1102 and the remainder of Article XI also raises the question of why a distinction should be made between the proof of authority necessary to transfer Pennsylvania stock under Section 1102, and the proof necessary to transfer assets under Article XI generally. For Section 1102, a certificate of appointment only is necessary; for Article XI generally, production of an exemplified copy of the will or probate proceedings in which the fiduciary was appointed is necessary. Since the purpose to be served in both situations is to prevent fraud upon the decedent's estate, no logical reason for the distinction suggests itself. If the mere submission of the certificate of appointment affords adequate protection in the case of stock transfers, it would be more in accord with the liberal spirit of the Act to permit this simplified method of proof whenever personal property is involved..$^{188}$

The 1917 Act specifically provided that foreign fiduciaries could sell when given power in the will, ${ }^{189}$ and although the 1949 Act has no such provision, there can be little doubt that the broad powers given by Article XI would permit a sale by a foreign fiduciary in such a case. Where there is no power of sale in the will the foreign fiduciary can sell under the 1949 Act if the law of the domiciliary jurisdiction provides for sale without order of court. Where the will does not specifically give the foreign fiduciary the power of sale and where the laws of the domiciliary jurisdiction require a court order before sale, Article XI presents a question as to whether a Pennsylvania or foreign court must give the order. The answer depends on the interpretation given to the requirement that a foreign fiduciary must not exercise any powers not granted in his domiciliary jurisdiction. An

187. PA. SEN. Bill No. 5 (1951).

188. Since the law of the situs governs the disposition of real property, no disposition of Pennsylvania realty by a will which did not meet the requirements of a Pennsylvania will would be effective. Hence there is a valid basis for requiring the foreign fiduciary to produce the will before exercising any power over Pennsylvania realty. But where only personalty is involved the requirement that the foreign fiduciary produce an exemplified copy of both the will and the probate proceedings seems unnecessary if it is assumed as it is in $\$ 1102$ that the certificate of appointment is sufficient proof of the fiduciaries authority to protect the estate from fraud.

189. Act of $1917, \S 996$. 
argument could be made that if the fiduciary got an order from the Pennsylvania courts he would not be exceeding the powers granted by the domiciliary jurisdiction because he is not selling real estate without an "order of court." The fact that only a Pennsylvania court can effectively order the sale of Pennsylvania real estate would tend to support this interpretation. The concept that a court of one state can not enlarge the powers granted to a fiduciary appointed in another state ${ }^{190}$ might, however, force the court to hold that the foreign fiduciary must get the permission of his own court before selling real estate. A practical consideration behind this view is that it is usually in the domiciliary state where the bulk of creditors are located and hence the domiciliary court is in a better position to determine whether the sale is necessary. When the problem actually arises, it might be cheaper in the long run for the foreign fiduciary to take out ancillary administration so that he could exercise the same powers, with regard to the sale of land, as possessed by local fiduciaries.

The 1917 Act made no provision for voluntary payments to foreign fiduciaries. However, the cases have held that, in the absence of creditors, legatees, or heirs within the state, a debtor can pay without subsequent liability to an ancillary administrator. Section 1105 of the 1949 Act protects a debtor even though there are creditors within this state by releasing him from any further liability when he has changed his position in reliance on any of the powers granted to foreign fiduciaries by this Act.

190. See Jones Estate, $28 \mathrm{~Pa}$. Dist. 282 (1928). (Pennsylvania Orphans' Court cannot give authority to sell land when the will does not give that Dower). 